\title{
JOURNAL.RU
}

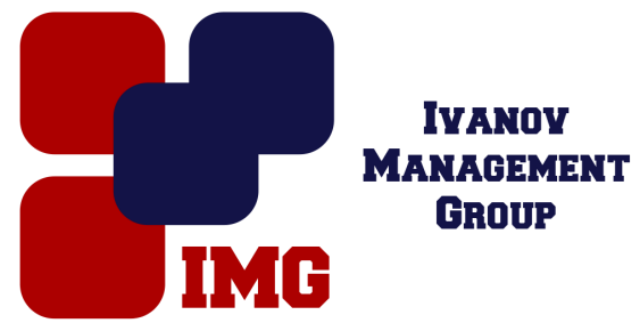

Latypov A.I. Astrakhan State Technical University Astrakhan, Россия

doi: $10.18411 / 1 \mathrm{j}-31-05-2017-19$

idsp 000001:1j-31-05-2017-19

\section{Formation of foreign language competence of students of non-linguistic universities}

\begin{abstract}
The role of a foreign language in Russian society has changed significantly over the last decades: its status has increased. Foreign language began to be considered as a means of providing people's livelihood as one of the important factors of intercultural and social interaction.

Keywords: foreign language competence, professional intercultural communication, language training of the future specialists.

The change of the position of foreign language in society has caused a number of updates in the learning process: revision of learning objectives, introduction of new methods, modernization of techniques. By the end of the training, the society wants to see a specialist with an appropriate level of knowledge not only in his sphere of work, but also with sufficiently highly developed foreign language competence. Thus, it is necessary to train specialists not only with the knowledge of a foreign language as a system, but also with a readiness to carry out professional intercultural communication $[3,140]$. That is, a graduate of the university should have a foreign language at such a level that his professionalism will be justified.

The problem of language competence arose at the beginning of the 20th century. At the core of the competence there is the inherent knowledge of the basic skills and ability of the student to construct for himself grammar rules of making sentences perceived in the language environment. Thus, the foreign language competence includes the mastery of a foreign language at the appropriate level within the topics,
\end{abstract}


providing non-linguistic education on the basis of everyday and professional vocabulary.

Modern authors define the concept of "competence" as "intellectual and personal ability of a person to practical activities, and "competence" as a substantial component of this ability in the form of knowledge and skills". Foreign language competence broadens the outlook of a specialist, allows him to conduct his professional activity more successfully in modern conditions, especially with foreign partners. The potential of focused language training is integrating beginning of the formation of foreign language competence.

The formation of foreign language competence is a complex process in a nonlinguistic institution for a number of reasons: insufficient number of hours, the workload of students in core subjects, lack of motivation of learning a foreign language, as well as the lack of successful and precise method of foreign language teaching and its isolation from professional training of the future specialist. Therefore, the country's leading universities have chosen the program "Professional Language" ("English for Special Purposes") as a way to improve the current situation. The development and implementation of new-generation domestic textbooks for students of non-linguistic universities is regarded as an indispensable condition for optimizing the teaching of a foreign language, which creates favorable conditions for the development of a foreign language competence. While developing curriculum for classroom and independent work, special attention is given to a modular system that allows to create skills in stages, basing on separate topics and the level of complexity of modules.

In this regard, the role of the teacher in a technical University is changing: he should not only provide the students with language training but also orient them to use the foreign language practically outside the classroom: in business, engineering and science, and just in dealing with people.

The problem situations are of particular value in the process of formation of foreign language competence. Students are offered the situations dictated by the reallife conditions: the open day at the University, submission of documents to foreign University, the discussion of the report at a scientific conference or finding necessary information in Internet. Such tasks contribute to the development of skills in the practical application of knowledge, develop independence and make students show their own initiative.The situation of role communication is a stimulus to the spontaneous speech development if it is related to the solution of communicative 
tasks. This type of work is aimed at the development of intellectual activity, and to overcome the psychological language barrier.

University students and graduates have to work with a large volume of scientific and professional literature in a foreign language. Therefore, foreign-language competence is formed in such activities as the preparation of the abstract, annotation and summarizing texts. This type of activity achieves the best effect when the material encourages students to analyze the information received, to search for necessary arguments, to generalize information leaning on one's experience. The success of students' educational activity of non-linguistic universities studying a foreign language is determined by many factors: high motivation of students to master a foreign language; accounting by the teacher the individual psychological peculiarities of students; inclusion of students in foreign language activities that bring a sense of satisfaction etc. [3,142].

The usage of information technology during the educational course gives students an access to a wide range of modern information. The application of computer tools and information sources of the Internet contributes to the development of a high level of information competence, a modern view of the technical sciences and the formation of professional thinking in a foreign language.

Students accumulate all the information about their qualifications, achievements and experience in learning a foreign language in the so-called language portfolio, which is becoming increasingly widespread in the system of language learning. This is a package of documents which is presented by every student studying a foreign language. It includes the evidence of his or her activities collected for a certain period of time, including samples of independent work, certificates, etc. The language portfolio is a step towards independent thinking, self-analysis and selfevaluation, which leads to the improvement of foreign-language competence.

$$
* * *
$$

1. Андриенко А. С. Формирование иноязычной профессиональной компетенции студентовбакалавров на основе чтения научно-технических текстов. // Вопросы современной филологии и методики обучения языкам в школе и вузе. - Пенза. - 2003 г., с. 168 - 170.

2. Митрофаненко Л.М. К вопросу о формировании иноязычной компетенции студентов неязыкового ВУЗа // Материалы ХIII научно-технической конференции // Вузовская наука - СевероКавказскому региону. Том 2-2009. - С.181.

3. Прохорова Т.Н., Нурмухамбетова С.А. К вопросу о формировании коммуникативной готовности к овладению иностранным языком у студентов неязыковых специальностей // Гуманитарные исследования, Астрахань. - 2015. - № 2 (июнь). - С. 138-142.

4. Нурмухамбетова С.А., Трудности межличностной коммуникации в педагогической практике // Сборники конференции НИЦ Социосфера. 2010. №8. С. 50-53. 